\title{
Antifungal activity of essential oil and its constituents from Calocedrus macrolepis var. formosana Florin leaf against plant pathogenic fungi
}

\author{
Hui-Ting Chang ${ }^{\mathrm{a}, *}$, Ying-Hung Cheng ${ }^{\mathrm{a}}$, Chi-Lin $\mathrm{Wu}^{\mathrm{a}}$, Shang-Tzen Chang ${ }^{\mathrm{a}}$, \\ Tun-Tschu Chang ${ }^{\mathrm{b}}$, Yu-Chang $\mathrm{Su}^{\mathrm{c}}$ \\ ${ }^{a}$ School of Forestry and Resource Conservation, National Taiwan University, Taipei 106, Taiwan \\ ${ }^{\mathrm{b}}$ Division of Forest Protection, Taiwan Forestry Research Institute, Taipei 100, Taiwan \\ ${ }^{\mathrm{c}}$ Department of Forestry, National Chung-Hsing University, Taichung 402, Taiwan
}

Received 10 October 2007; received in revised form 28 November 2007; accepted 1 December 2007

Available online 21 February 2008

\begin{abstract}
Resistance to conventional fungicides causes the poor disease control of agriculture. Natural products from plants have great potential as novel fungicide sources for controlling pathogenic fungi. In this study antipathogenic activity of the leaf essential oil and its constituents from Calocedrus macrolepis var. formosana Florin were evaluated in vitro against six plant pathogenic fungi. Chemical analysis of leaf oil by GC/MS allowed identification of $\alpha$-pinene $(44.2 \%)$, limonene $(21.6 \%)$, $\beta$-myrcene $(8.9 \%)$, $\beta$-caryophyllene $(8.2 \%)$, caryophyllene oxide $(2.4 \%)$, $\alpha$-cadinol $(1.6 \%), \beta$-pinene $(1.2 \%)$, and T-muurolol $(1.1 \%)$ as main components. Sesquiterpenoid components of the oil were more effective than monoterpenoid components of the oil. In particular, T-muurolol and $\alpha$-cadinol strongly inhibited the growth of Rhizoctonia solani and Fusarium oxysporum, with the $\mathrm{IC}_{50}$ values $<50 \mu \mathrm{g} \mathrm{ml}^{-1}$. These compounds also efficiently inhibited the mycelial growths of Colletotrichum gloeosporioides, P. funerea, Ganoderma australe and F. solani. These results showed that T-muurolol and $\alpha$-cadinol possess antifungal activities against a broad spectrum of tested plant pathogenic fungi and could be used as potential antifungal agents for the control of fungal diseases in plants.
\end{abstract}

(C) 2007 Elsevier Ltd. All rights reserved.

Keywords: Calocedrus macrolepis var. formosana Florin; Plant pathogenic fungi; Antifungal activity; T-Muurolol; $\alpha$-Cadinol

\section{Introduction}

Plant pathogens include fungi, nematodes, bacteria, and viruses which can cause diseases or damages in plants (Montesinos, 2003). Among these pathogens, fungi are the main pathogen and cause many diseases of plants. Pathogenic fungi also cause yield losses in numerous economically important crops (Fletcher et al., 2006). Hussein et al. (2002) found that most of grains in maize fields were infected with Fusarium species, and soil can be considered as one of the important inoculum sources for these species.

\footnotetext{
* Corresponding author. Tel.: +88623366 5880; fax: +886223654520. E-mail address: chtchang@ntu.edu.tw (H.-T. Chang).
}

Ganoderma is a polyporoid fungus and has a worldwide distribution. Sankaran et al. (2005) reported that Ganoder$m a$ causes a decrease of production and death of various plants, such as cash crops and trees in India. Several fungi have been found to induce post-harvest spoilage of sweet potato, which is associated with decrease in starch, total sugar and organic acid (Ray and Ravi, 2005). Diseases caused by fungi are also the serious problem in forest management. Damping-off of seedlings caused by Rhizoctonia solani were frequently observed on many woody perennial plants (Chang, 1997). Colletotrichum gloeosporioides causes anthracnose disease of trees and results in leaf spots and defoliation (Chang et al., 1997). Trees infected with $F$. solani showed root crown rot, dieback and wilt $(\mathrm{Fu}$ and Chang, 1999; Demirci and Maden, 2006). 
Chemical treatments with soil amendments are the main solutions for pathogenic disease control of plants (Montesinos, 2003; Nunes et al., 2001). Synthetic fungicides are helpful to sustaining crop production by protecting plants from fungal diseases. Resistance to fungicides is one of critical causes of poor disease control of agriculture (Steffens et al., 1996; Aguin et al., 2006; Ishii, 2006). There are, therefore, needs to develop alternative agents for the control of pathogenic fungal diseases in plants. Biocontrol activities of enzymes were also investigated against pathogenic fungi (Prabavathy et al., 2006; Chang et al., 2007). In addition, several studies on the fungitoxic activities of plant secondary metabolites have been reported (Muller-Riebau et al., 1995; Ojala et al., 2000; Kordali et al., 2003; Nunez et al., 2006; Field et al., 2006; Lee, 2007).

Pitarokili et al. (2003) reported that volatile essential oil of Salvia fruticosa was effective against phytopathogenic fungi, including $R$. solani, Sclerotinia sclerotiorum, and $F$. solani. Leaf essential oils of Thymbra spicata, Satureja thymbra, and Origanum minitiflorum, growing wild in Turkey, were strongly inhibitory to the growth of the soil-borne plant disease-causing fungi $F$. moniliforme, $R$. solani, S. sclerotiorum, and Phytophthora capsici (Muller-Riebau et al., 1995). Antifungal diterpenoids were isolated from the bark extract of Cryptomeria japonica, and the antifungal activities of these components were evaluated against phytopathogenic fungi (Kofujita et al., 2006).

Calocedrus macrolepis var. formosana Florin (Taiwan incense cedar), coniferous evergreen tree, is one of the precious endemic woods in Taiwan, it belongs to the family of Cupressaceae. The chemical composition of C. macrolepis var. formosana leaf essential oil and its antifungal activity against wood-rot fungi has been previously reported by our research group (Cheng et al., 2004). In continuation of our investigation on bioactivities of the leaf oil and its constituents from C. macrolepis var. formosana against several important plant pathogenic fungi were evaluated in this study.

\section{Methods}

\subsection{Plant materials}

Leaves were collected from Calocedrus macrolepis var. formosana Florin tree (41 years of age) in the Experimental Forest of National Taiwan University. The species was identified, and a voucher specimen was deposited in the laboratory of wood chemistry (School of Forestry and Resource Conservation, National Taiwan University).

\subsection{Plant pathogenic fungi}

Six common plant pathogenic fungi were selected for the present study and purchased from Bioresource Collection and Research Center (BCRC) of Taiwan. Fusarium oxysporum f. sp. melonis Snyder \& Hansen (BCRC32121) and
Rhizoctonia solani Kuhn (BCRC31626) are usual damping-off pathogens of plants. Pestalotiopsis funerea (Desmazieres) Steyaert (BCRC35266) and Colletotrichum gloeosporioides Penzig (BCRC35003) cause many leaf diseases, such as anthracnose. Ganoderma australe (Fries) Paterson (BCRC36246) and Fusarium solani (Martius) Saccardo (BCRC32458) are the important root rot pathogens of plants. Each fungal strain was cultured in potato dextrose agar (PDA, Difco Company).

\subsection{Distillation of sample plant}

Fresh leaves of $C$. macrolepis var. formosana were hydrodistilled in a Clevenger-type apparatus for $8 \mathrm{~h}$ to obtain essential oil. Leaves were in boiling water during distillation. Yield of leaf essential oil was $0.3 \%$.

\subsection{GC/MS analysis of essential oil}

The composition of the oil was analyzed using HewlettPackard 6890 gas chromatograph and Agilent Technologies HP 5973N mass spectrometry equipped with a HP$1 \mathrm{MS}$ capillary column (100\% Dimethylpolysiloxane; $30 \mathrm{~m} \times 0.25 \mathrm{~mm}$; film thickness $0.25 \mu \mathrm{m}$ ). Oven temperature was initially held at $50{ }^{\circ} \mathrm{C}$ for $5 \mathrm{~min}$, then increased to $120^{\circ} \mathrm{C}$ at a rate of $2{ }^{\circ} \mathrm{C} \mathrm{min}^{-1}$ and increased to $220^{\circ} \mathrm{C}$ at a rate of $5^{\circ} \mathrm{C} \mathrm{min}{ }^{-1}$ and held for $5 \mathrm{~min}$. Carrier gas was helium at a flow rate of $1 \mathrm{ml} \mathrm{min}{ }^{-1}$, and the split ratio was 1:10. Components were identified by comparing their mass spectra with Wiley and NIST library data and standards of the main components. Quantification of components was obtained by integrating the peak area of the chromatogram.

\subsection{Antifungal assay}

Leaf oil and its main constituents were dissolved in $150 \mu \mathrm{L}$ of ethanol, respectively, and then added into $15 \mathrm{ml}$ PDA to obtain the different final concentrations. Mycelial plugs ( $5 \mathrm{~mm}$ in diameter) from the edges of each culture were incubated in the center of each PDA plate $(90 \mathrm{~mm}$ diameter). Cultures were incubated in the dark at $26{ }^{\circ} \mathrm{C}$ and $70 \% \mathrm{RH}$ for ca. $8-14$ days. Tests were repeated in triplicate. Antifungal index was calculated as the following: Antifungal index $(\%)=(1-\mathrm{Da} / \mathrm{Db}) \times 100$, where $\mathrm{Da}$ : the diameter of growth zone in the test plate. $\mathrm{Db}$ : the diameter of growth zone in the control plate. $\mathrm{IC}_{50}$ (concentration that produces a $50 \%$ inhibitory effect) values of constituents were graphically obtained from the doseresponse curves based on measurement at five different concentrations.

\subsection{Statistical analysis}

Mean values and standard deviations were calculated for all tests. The data were grouped by Scheffe's test of the SAS system (at a level of significance of $p<0.05$ ). 


\section{Results and discussion}

\subsection{Antifungal activity of C. macrolepis var. formosana leaf oil}

The antifungal effects of leaf oil of $C$. macrolepis var. formosana against plant pathogenic fungi are shown in Fig. 1. The antifungal indexes of leaf oil against damping-off pathogens, Fusarium oxysporum (F.o.) and Rhizoctonia solani (R.s.), were $15.0 \%$ and $33.1 \%$ at a $2 \mathrm{mg} \mathrm{ml}^{-1}$ concentration. As for the pathogens which caused leaf infections of plants, the antifungal indexes of the oil were $65.0 \%$ and $16.7 \%$ against Pestalotiopsis funerea (P.f.) and Colletotrichum gloeosporioides (C.g.), respectively. The antifungal indexes of the oil against root rot pathogens, Ganoderma australe (G.a.) and Fusarium solani (F.s.), were $22.5 \%$ and $52.1 \%$, respectively. These results showed that leaf oil was highly inhibitory to mycelial growth of $P$. funerea and $F$. solani among the pathogens tested.

\subsection{Chemical component analysis and antifungal activities of the constituents against damping-off pathogens}

The chemical characterization of the leaf oil by GC/MS previously allowed identification of $\alpha$-pinene (44.2\%), limonene $(21.6 \%), \beta$-myrcene $(8.9 \%)$, $\beta$-caryophyllene $(8.2 \%)$, caryophyllene oxide $(2.4 \%), \alpha$-cadinol $(1.6 \%), \beta$-pinene $(1.2 \%)$ and T-muurolol $(1.1 \%)$ as main components (Cheng et al., 2004). It also contains some other constituents in minor level $(<1 \%)$.

Fig. 2 shows the antifungal activities of leaf oil constituents against damping-off pathogens, $R$. solani and $F$. oxysporum. Antifungal activities of $\alpha$-pinene and $\beta$-pinene were less than $10 \%$ at a concentration of $200 \mu \mathrm{g} \mathrm{ml}^{-1}$ (data are not shown in Fig. 2). Limonene and $\beta$-myrcene also showed the weak antifungal activities. Results of these monoterpenoids are consistent with the data reported by Cakir et al. (2004) against $R$. solani and $F$. oxysporum. Sesquiterpenoids, $\beta$-caryophyllene, caryophyllene oxide,

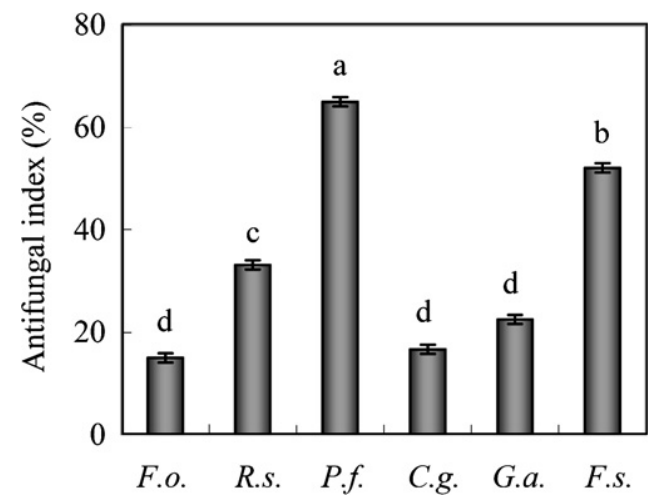

Fig. 1. Antifungal activities of the leaf oil $\left(2 \mathrm{mg} \mathrm{ml}^{-1}\right)$ from Calocedrus macrolepis var. formosana against the plant pathogenic fungi. Bars with different letters (a-d) are statistically different at $p<0.05$ according to the Scheffe's test.

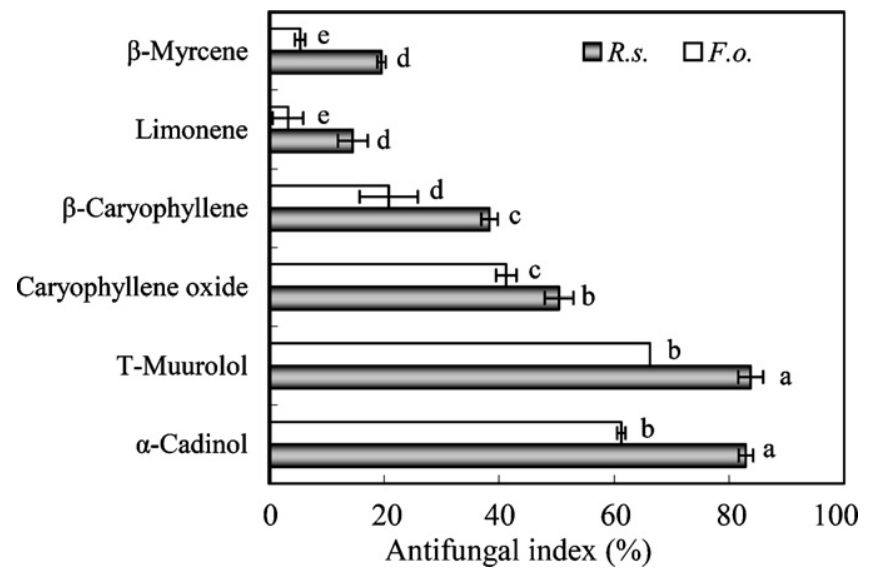

Fig. 2. Antifungal activities of the constituents $\left(200 \mu \mathrm{g} \mathrm{ml}^{-1}\right)$ of Calocedrus macrolepis var. formosana leaf oil against the seedling pathogenic fungi. Bars with different letters (a-e) are statistically different at $p<0.05$ according to the Scheffe's test.

T-muurolol and $\alpha$-cadinol, exhibited better activities among leaf oil constituents. T-muurolol and $\alpha$-cadinol exhibited strong activity against $R$. solani and $F$. oxysporum with the highest antifungal indexes ranging from $60 \%$ to $85 \%$. IC $\mathrm{IC}_{50}$ values of $\mathrm{T}$-muurolol against $R$. solani and $F$. oxysporum were 15.2 and 34.2 and $\alpha$-cadinol had $\mathrm{IC}_{50}$ values of 21.0 and $30.1 \mu \mathrm{g} \mathrm{ml}^{-1}$ against $R$. solani and $F$. oxysporum (Table 1). Muller-Riebau and coauthors (1995) found that inhibition values of thymol, a fungicide, were $34.2 \%$ against $R$. solani at a concentration of $50 \mu \mathrm{g} \mathrm{ml}^{-1}$. It revealed that $\alpha$-cadinol would be more effective compared to thymol. Among the antifungal constituents isolated from Taiwania cryptomerioides heartwood extract (Chang et al., 2000), it was reported that $\alpha$-cadinol completely inhibited the growth of wood-rot fungi, Coriolus versicolor and Laetiporus sulphureus, at a concentration of $100 \mu \mathrm{g} \mathrm{ml}^{-1}$. These results manifested that $\alpha$-cadinol has a wide spectrum of antifungal activity.

\subsection{Antifungal activities of the oil constituents against pathogens causing leaf diseases}

C. gloeosporioides is one of the important pathogens of plants which cause leaf spotting, dieback of twigs, death

Table 1

$\mathrm{IC}_{50}$ values of sesquiterpenoid constituents of Calocedrus macrolepis var. formosana leaf oil against plant pathogenic fungi

\begin{tabular}{|c|c|c|c|c|c|c|}
\hline \multirow[t]{2}{*}{ Constituents } & \multicolumn{6}{|c|}{ Plant pathogenic fungi } \\
\hline & R.s. & F.o. & C.g. & P.f. & F.s. & G.a. \\
\hline$\beta$-Caryophyllene & - & - & 57.9 & - & 92.3 & - \\
\hline Caryophyllene oxide & 125.9 & 164.0 & 66.1 & - & 70.2 & - \\
\hline T-Muurolol & 15.2 & 34.2 & 17.1 & 87.3 & 17.3 & 93 \\
\hline$\alpha$-Cadinol & 21.0 & 30.1 & 11.7 & 51.9 & 36.5 & 44.3 \\
\hline
\end{tabular}

R.s.: Rhizoctonia solani; F.o.: Fusarium oxysporum; C.g.: Colletotrichum gloeosporioides; P.f.: Pestalotiopsis funerea; G.a.: Ganoderma australe; F.s.: Fusarium solani; Unit: $\mu \mathrm{g} \mathrm{ml}^{-1}$; -: $\mathrm{IC}_{50}$ value $>200 \mu \mathrm{g} \mathrm{ml}^{-1}$. 


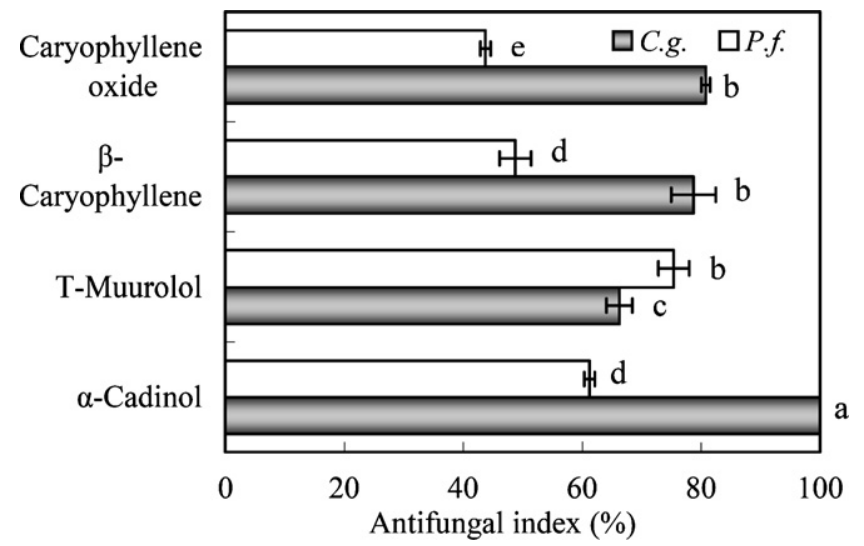

Fig. 3. Antifungal activities of sesquiterpenoid constituents $\left(200 \mu \mathrm{g} \mathrm{ml}^{-1}\right)$ of Calocedrus macrolepis var. formosana leaf oil against the leaf pathogenic fungi. Bars with different letters (a-e) are statistically different at $p<0.05$ according to the Scheffe's test.

of foliage, and post-harvest problems (Chang et al., 1997; Almada-Ruiz et al., 2003). Among leaf oil constituents, $\alpha$-pinene, $\beta$-pinene, $\beta$-myrcene and limonene cannot inhibit the growth of $C$. gloeosporioides at a concentration of $200 \mu \mathrm{g} \mathrm{ml}^{-1}$ (data are not shown in Fig. 3). The better antifungal activities were found for sesquiterpenoid constituents. It is obvious that $\alpha$-cadinol exhibited the highest antifungal activity completely inhibiting the growth of $C$. gloeosporioides. $\mathrm{IC}_{50}$ values of $\beta$-caryophyllene, caryophyllene oxide, T-muurolol, and $\alpha$-cadinol were found as 57.9, 66.1, 17.1, and $11.7 \mu \mathrm{g} \mathrm{ml}^{-1}$ (Table 1), respectively. Antifungal indexes of four sesquiterpenoid against $P$. funerea ranged from $40 \%$ to $80 \%$ (Fig. 3). Only T-muurolol and $\alpha$-cadinol can effectively inhibit the mycelial growth of $P$. funerea with $\mathrm{IC}_{50}$ values of 87.3 and $51.9 \mu \mathrm{g} \mathrm{ml}^{-1}$, respectively.

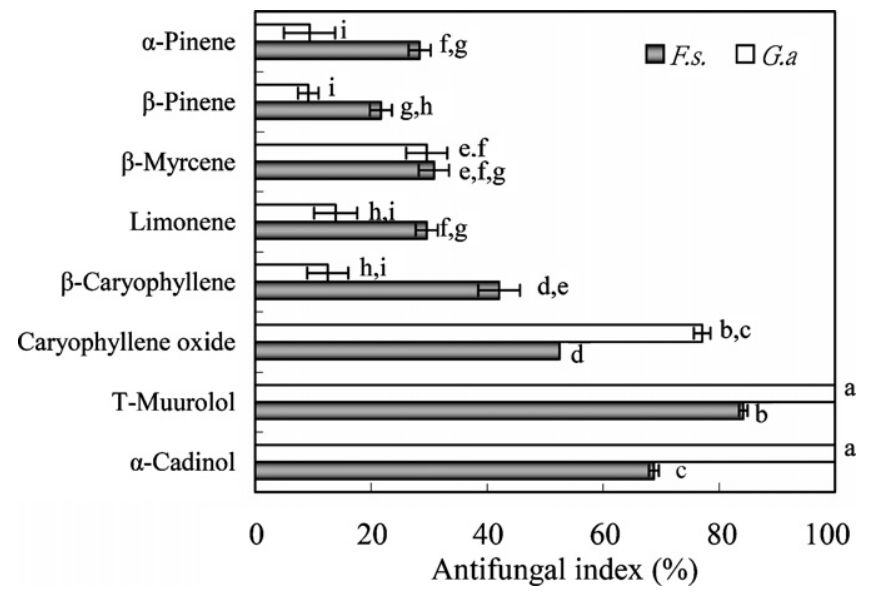

Fig. 4. Antifungal activities of the constituents $\left(200 \mu \mathrm{g} \mathrm{ml}^{-1}\right)$ of Calocedrus macrolepis var. formosana leaf oil against the root pathogenic fungi. Bars with different letters $(\mathrm{a}-\mathrm{i})$ are statistically different at $p<0.05$ according to the Scheffe's test.
3.4. Antifungal activities of the oil constituents against root rot pathogens

As shown in Fig. 4, caryophyllene oxide, T-muurolol, and $\alpha$-cadinol possessed significant antifungal activities (antifungal index $>50 \%$ ) against $F$. solani at a concentration of $200 \mu \mathrm{g} \mathrm{ml}^{-1}$. T-Muurolol also showed noticeable activity with an $\mathrm{IC}_{50}$ value, $17.3 \mu \mathrm{g} \mathrm{ml}^{-1}$ (Table 1). Antifungal activities of leaf oil constituents against $G$. australe are presented in Fig. 4. Mycelial growth of $G$. australe was completely inhibited by T-muurolol and $\alpha$-cadinol at a concentration of $200 \mu \mathrm{g} \mathrm{ml}^{-1}$, whereas $\alpha$-cadinol had a lowest $\mathrm{IC}_{50}$ value $\left(44.3 \mu \mathrm{g} \mathrm{ml}^{-1}\right)$ against $G$. australe.

\section{Conclusions}

The present results show that, among the tested pathogenic fungi, the antifungal activities of leaf oil against $F$. solani and $P$. funerea were greater than that of the other fungi. Antifungal activities of sesquiterpenoid constituents were superior to those of its monoterpenoid constituents. Among active sesquiterpenoids, T-muurolol and $\alpha$-cadinol possess the best activity against plant pathogenic fungi. Results suggest that C. macrolepis var. formosana leaf oil, T-muurolol and $\alpha$-cadinol could be used as potential natural fungicide for controlling fungal pathogens and worth further investigation.

\section{Acknowledgements}

This study was funded by a NSC (National Science Council of Taiwan) project (NSC932313B002014). Authors would like to thank NSC for financially supporting and the Experimental Forest of National Taiwan University for providing the plant materials.

\section{References}

Aguin, O., Mansilla, J.P., Maria, J.S., 2006. In vitro selection of an effective fungicide against Armillaria mellea and control of white root rot of grapevine in the field. Pest Manag. Sci. 62, 223-228.

Almada-Ruiz, E., Martinez-Tellez, M.A., Hernandez-Alamos, M.M., Vallejo, S., Primo-Yufera, E., Vargas-Arispuro, I., 2003. Fungicidal potential of methoxylated flavones from citrus for in vitro control of Colletotrichum gloeosporioides, causal agent of anthracnose disease in tropical fruits. Pest Manag. Sci. 59, 1245-1249.

Cakir, A., Kordali, S., Zengin, H., Izumi, S., Hirata, T., 2004. Composition and antifungal activity of essential oils isolated from Hypericum hyssopifolium and Hypericum heterophyllum. Flavour Fragr. J. 19, 6268.

Chang, T.T., 1997. Damping-off of Casuarina junghuhniana and Lagerstroemia speciosa caused by Rhizoctonia solani. Taiwan J. For. Sci. 12, $47-52$.

Chang, T.T., Chern, L.L., Chiu, W.H., 1997. Anthracnose and brown root rot of Cinnamomum kenehirae. Taiwan J. For. Sci. 12, 373-378.

Chang, S.T., Wang, D.S.Y., Wu, C.L., Chen, P.F., Kuo, Y.H., 2000. Comparison of the antifungal activity of cadinane skeletal sesquiterpenoids from Taiwania (Taiwania cryptomerioides Hayata) heartwood. Holzforschung 54, 241-245. 
Chang, W.T., Chen, Y.C., Jao, C.L., 2007. Antifungal activity and enhancement of plant growth by Bacillus cereus grown on shellfish chitin wastes. Bioresour. Technol. 98, 1224-1230.

Cheng, S.S., Wu, C.L., Chang, H.T., Kao, Y.T., Chang, S.T., 2004. Antitermitic and antifungal activities of essential oil of Calocedrus formosana leaf and its composition. J. Chem. Ecol. 30, 1957-1967.

Demirci, F., Maden, S., 2006. A severe dieback of box elder (Acer negundo) caused by Fusarium solani (Mart) Sacc. in Turkey. Austral. Plant. Dis. Notes 1, 13-15.

Field, B., Jorden, F., Osbourn, A., 2006. First encounters - deployment of defense-related natural products by plants. New Phytol. 172, 193-207.

Fletcher, J., Bender, C., Budowle, B., Cobb, W.T., Gold, S.E., Ishimaru, C.A., Luster, D., Melcher, U., Murch, R., Scherm, H., Seem, R.C., Sherwood, J.L., Sobral, B.W., Tolin, S.A., 2006. Plant pathogen forensics: capabilities, needs, and recommendations. Microbiol. Mol. Biol. Rev. 70, 450-471.

Fu, C.H., Chang, T.T., 1999. Foot rot of Ardisia crenata caused by Fusarium solani. Taiwan J. For. Sci. 14, 223-227.

Hussein, H.M., Christensen, M.J., Baxter, M., 2002. Occurrence and distribution of Fusarium species in maize fields in New Zealand. Mycopathologia 156, 25-30.

Ishii, H., 2006. Impact of fungicide resistance in plant pathogens on crop disease control and agricultural environment. Jpn. Agric. Res. Q. 40, 205-211.

Kofujita, H., Fujino, Y., Ota, M., Takahashi, K., 2006. Antifungal diterpenes from the bark of Cryptomeria japonica D. Don. Holzforschung $60,20-23$.

Kordali, S., Cakir, A., Zengin, H., Duru, M.E., 2003. Antifungal activities of the leaves of three Pistacia species grown in Turkey. Fitoterapia 74, 164-167.

Lee, H.S., 2007. Fungicidal property of active component derived from Acorus gramineus rhizome against phytopathogenic fungi. Bioresour. Technol. 98, 1324-1328.
Montesinos, E., 2003. Development, registration and commercialization of microbial pesticides for plant protection. Int. Microbiol. 6, 245252.

Muller-Riebau, F., Berger, B., Yegen, O., 1995. Chemical composition and fungitoxic properties to phytopathogenic fungi of essential oils of selected aromatic plants growing wild in Turkey. J. Agric. Food Chem. 43, 2262-2266.

Nunes, C., Usall, J., Teixido, N., Eribe, X.O., Vinas, I., 2001. Control of postharvest decay of apples by pre-harvest and post-harvest application of ammonium molybdate. Pest Manag. Sci. 57, 1093-1099.

Nunez, Y.O., Salabarria, I.S., Collado, I.G., Hernandez-Galan, R., 2006. The antifungal activity of widdrol and its biotransformation by Colletotrichum gloeosporioides (penz) Penz. \& Sacc. and Botrytis cinerea Pers. Fr. J. Agric. Food Chem. 54, 7517-7521.

Ojala, T., Remes, S., Haansuu, P., Vuorela, H., Hiltunen, R., Haahtela, K., Vuorela, P., 2000. Antimicrobial activity of some coumarin containing herbal plants growing in Finland. J. Ethnopharmacol. 73, 299-305.

Pitarokili, D.P., Tzakou, O., Loukis, A., Harvala, C., 2003. Volatile metabolites from Salvia fruticosa as antifungal agents in soilborne pathogens. J. Agric. Food Chem. 51, 3294-3301.

Prabavathy, V.R., Mathivanan, N., Sagadevan, E., Murugesan, K., Lalithakumari, D., 2006. Self-fusion of protoplasts enhances chitinase production and biocontrol activity in Trichoderma harzianum. Bioresour. Technol. 97, 2330-2334.

Ray, R.C., Ravi, V., 2005. Post harvest spoilage of sweet potato in tropics and control measures. Crit. Rev. Food Sci. Nutr. 45, 623-644.

Sankaran, K.V., Bridge, P.D., Gokulapalan, C., 2005. Ganoderma diseases of perennial crops in India - an overview. Mycopathologia $159,143-152$.

Steffens, J.J., Pell, E.J., Tien, M., 1996. Mechanisms of fungicide resistance in phytopathogenic fungi. Curr. Opin. Biotechnol. 7, 348-355. 